\title{
Pengaruh Model Realistic Mathematics Education (RME) Berbantu Media Kertas Lipat Terhadap Penanaman Konsep Bangun Datar
}

\author{
* Rizma Vira Artika1 ${ }^{1}$, Rahmat Sudrajat ${ }^{2}$, Arfilia Wijayanti ${ }^{3}$ \\ ${ }^{123}$ Jurusan Pendidikan Guru Sekolah Dasar, Universitas PGRI Semarang, Indonesia
}

\section{A R T I C L E I N F O}

\section{Article history:}

Received 15 August 2019 Received in revised form 20 September 2019

Accepted 10 October 2019

Available online 27

November 2019

\section{Kata Kunci:}

rme, kertas lipat,

penanaman konsep bangun

datar.

Keywords:

RME, paper folding, flat

build concept planting.

\begin{abstract}
A B S T R A K
Fenomena di sekolah menunjukkan bahwa dalam pembelajaran matematika masih terdapat kecenderungan guru jarang menggunakan media/alat peraga, guru menggunakan media/alat peraga seadanya atau sangat sederhana, dan dikemas dengan cara yang kurang menarik perhatian siswa. Kondisi yang demikian menjadikan pembelajaran matematika tidak menarik dan tidak menyenangkan, sehingga tidak optimal dalam membantu siswa untuk memperoleh konsep-konsep matematika.Tujuan yang akan dicapai dalam penelitian ini adalah untuk mengetahui apakah model RME berbantu media kertas lipat berpengaruh terhadap penanaman konsep bangun datar mata pelajaran matematika siswa kelas II SD. Jenis penelitian ini adalah kuantitatif dengan jenis pre-eksperimental design dengan jenis One-Group Pretest-Posttest. Populasi penelitian ini adalah siswa kelas II SD sejumlah 30 siswa. Analisis data dalam penelitian menggunakan uji normalitas awal pada nilai pretest, uji normalitas akhir pada posttest, uji
\end{abstract} regresi, serta uji ketuntasan belajar. Teknik pengumpulan data seperti tes dan dokumentasi. Hasil akhir dalam perhitungan uji regresi diperoleh harga $r_{\text {hitung }}=0,869$ sedangkan harga $r_{\text {tabel }}=0,361$, karena $r_{\text {hitung }}>r_{\text {tabel, }}$, maka hipotesis nol $\left(\mathrm{H}_{0}\right)$ ditolak dan hipotesis alternatif $\left(\mathrm{H}_{\mathrm{a}}\right)$ diterima. Hal tersebut dapat disimpulkan bahwa terdapat hubungan yang positif dan signifikan antara keterampilan siswa dengan penanaman konsep bangun datar mata pelajaran matematika siswa kelas II SD melalui penggunaan model RME berbantu media kertas lipat. Saran yang dapat disampaikan adalah model RME dapat digunakan guru sebagai salah satu model pembelajaran alternatif, karena model tersebut merupakan model yang menarik dan mudah diterapkan khususnya pada mata pelajaran matematika sebab model ini mengacu berdasarkan pengalaman siswa dan benda-benda nyata atau konkrit.

\section{A B S T R A C T}

The purpose of this research is to find out whether the RME model with the help of folding paper media influences the planting of the concept of flat figure of mathematics subjects in class II SDN Banyubiru 01. The type of this research is quantitative with pre-experimental design with One-Group Pretest type -Posttest. The population of this research is the second grade students of SDN Banyubiru 01 Semarang Regency, where the number of students of grade II SDN Banyubiru 01 Semarang Regency is 30 students. Data analysis in the study used the initial normality test on the pretest value, the final normality test at the posttest, the regression test, and the study completeness test. Data collection techniques such as tests and documentation. The final results in the calculation of the regression test obtained price $r$ count $=0.869$ while the price $r$ table $=0.361$, because $r$ count $r$ table, the null hypothesis $(\mathrm{HO})$ is rejected and the alternative hypothesis $(\mathrm{Ha})$ is accepted. It can be concluded that there is a positive and significant relationship between students' skills and the cultivation of the concept of flat shapes of mathematics subjects in class II SDN Banyubiru 01 through the use of RME models with the aid of folding paper media. The suggestion that can be delivered is that the RME model can be used by the teacher as one of the alternative learning models, because the model is an interesting model and is easy to apply especially in mathematics because this model is based on student experience and tangible or concrete objects.

Copyright (C) Universitas Pendidikan Ganesha. All rights reserved. 


\section{Pendahuluan}

Pendidikan merupakan suatu proses di mana pengalaman dan informasi diperoleh sebagai hasil belajar, yang mencakup pengertian dan penyesuaian diri dari pihak peserta didik terhadap rangsangan yang diberikan kepadanya menuju ke arah pertumbuhan dan perkembangan. Dengan demikian, pendidikan di sekolah dipengaruhi oleh beberapa faktor antara lain: guru, metode/pendekatan/model pembelajaran, kurikulum, media pengajaran, dan peserta didik.

Dalam rangka meningkatkan mutu pendidikan di Indonesia diperlukan upaya yang serius untuk meningkatkan kualitas guru. Seorang guru memiliki peran yang paling besar dalam upaya inovasi serta peningkatan mutu pendidikan melalui inovasi dalam proses pembelajaran. Peningkatan mutu pendidikan dapat dimulai dengan meningkatkan mutu guru dalam mengajar dan berprilaku profesional. Berbagai penataran dan pelatihan guru menjadi salah satu bentuk dari upaya tersebut walaupun kurang membekas dalam keseharian aktivitas guru. Hal inilah yang mendasari perlunya perbaikan yang menitik beratkan kepada kondisi nyata di lapangan, mulai dari kondisi di kelas, sekolah, dan guru. Pelaksanaan sertifikasi guru sebagai amanat dari Undang-undang (UU) Nomor 14 Tahun 2005 tentang Guru dan Dosen diharapkan berperan dalam peningkatan kualitas pendidikan (Monawati, 2017)

Pendidikan merupakan bagian yang sangat penting dalam proses pembangunan suatu bangsa dan negara, karena tanpa didukungnya pendidikan tidak mungkin pembangunan suatu bangsa dan negara dapat berkembang dengan baik (Sirait, 2016). Kita dapat melihat contohnya yaitu perkembangan antara desa dengan kota, dimana kota bisa dianggap lebih berkembang dari pada desa dikarenakan sistem pembangunan yang dipimpin oleh orang-orang terpelajar. Pendidikan itu sebenarnya harus didapatkan oleh setiap lapisan masyarakat agar pembangunan suatu bangsa dan negara itu dapat berjalan dengan baik. Hal tersebut juga terlihat dalam UUD 1945 pasal 31 yang menyatakan bahwa setiap warga negara berhak mendapatkan pendidikan (Amandemen UUD 1945, Bab XIII tentang Pendidikan dan Kebudayaan). Pernyataan dalam pasal 31 itu sekaligus merupakan landasan dan jaminan bagi setiap warga negara Indonesia untuk memperoleh pendidikan tanpa membedakan suku, agama, dan golongan. Hasil pendidikan yang diperoleh setiap warga negara diharapkan dapat meningkatkan kualitas sumber daya manusia Indonesia secara sendiri-sendiri atau keseluruhan di masa kini dan mendatang. Sumber daya manusia Indonesia yang berkualitas tersebut memiliki ciri sebagaimana tersebut dalam tujuan pendidikan nasional yaitu: Pendidikan nasional berfungsi mengembangkan kemampuan dan membentuk watak serta peradaban bangsa yang bermartabat dalam rangka mencerdaskan kehidupan bangsa, bertujuan untuk berkembangnya potensi peserta didik agar menjadi manusia yang beriman dan bertakwa kepada Tuhan Yang Maha Esa, berakhlak mulia, sehat, berilmu, cakap, kreatif, mandiri, dan menjadi warga negara yang demokratis serta bertanggung jawab (Suwartini, 2017). (UUD RI Sistem Pendidikan Nasional: 2003, 2) Tujuan pendidikan nasional di atas menunjukkan penting dan strategisnya peranan pendidikan dalam membentuk dan membangun generasi penerus bangsa. Untuk mencapai tujuan pendidikan nasional tersebut ditempuh jalur pendidikan sekolah dan jalur pendidikan luar sekolah. Pendidikan jalur sekolah memiliki tujuan yang berkaitan dengan tujuan pendidikan nasional, tujuan institusional, tujuan kurikuler sampai pada tujuan instruksional. Sedangkan pendidikan jalur luar sekolah memiliki tujuan yang berkaitan dengan institusi yang menyelenggarakan (Sirait, 2016).

Keberhasilan program pendidikan melalui kegiatan belajar mengajar di sekolah di pengaruhi oleh banyak faktor diantaranya yaitu kurikulum, guru, sarana dan prasarana, siswa, serta faktor lingkungan. Era globalisasi saat ini juga menuntut adanya sumber daya manusia yang berkualitas. Untuk mewujudkan sumber daya manusia yang berkualitas harus di dukung dengan adanya program pendidikan yang berkualitas pula.

Berdasarkan Undang-undang Sisdiknas No. 20 Tahun 2003 Pasal 3 disebutkan bahwa Pendidikan Nasional berfungsi mengembangkan kemampuan dan membentuk watak serta peradaban bangsa yang bermartabat dalam rangka mencerdaskan kehidupan bangsa, bertujuan untuk berkembangnya potensi peserta didik agar menjadi manusia yang beriman dan bertaqwa kepada Tuhan Yang Maha Esa, berakhlak mulia, sehat, berilmu, cakap, kreatif, mandiri dan menjadi warga Negara yang demokratis serta bertanggung jawab.

Pendidikan di Sekolah Dasar pada Kurikulum 2013 edisi revisi Tahun 2018 menggunakan sistem tematik dengan tujuan untuk mengintegrasikan beberapa mata pelajaran kedalam satu pembelajaran. Mata pelajaran yang dapat diintegrasikan adalah PPKn, Bahasa Indonesia, Matematika, Ilmu Pengetahuan Alam (IPA), Seni Budaya dan Prakarya (SBdP), Ilmu Pengetahuan Sosial (IPS), dan Pendidikan Jasmani, Olahraga dan Kesehatan (PJOK). Sehingga dengan pengintegrasian tersebut peserta didik dapat mengembangkan kemampuan berpikir dan penanaman pendidikan karakter untuk menjadi pribadi yang lebih baik lagi. Namun pada perkembangannya, untuk kelas tinggi yaitu kelas IV, V, dan VI ada beberapa mata pelajaran yang diajarkan secara terpisah dalam Kurikulum 2013 tematik terpadu sesuai dengan 
Permendikbud No 24 tahun 2016 yaitu mata pelajaran Agama, Pendidikan Jasmani, Olahraga dan Kesenian, dan mata pelajaran Matematika. Keputusan perpisahan mata pelajaran tersebut ada berbagai alasan, diantaranya muatan materi dan pembahasan.

Realistic Mathematics Education (RME) merupakan aktivitas insani (human activities) dan harus dikaitkan dengan realitas. RME mempunyai ciri antara lain, bahwa dalam proses pembelajaran siswa harus diberikan kesempatan untuk menemukan kembali (to reinvent) matematika melalui bimbingan guru (Gravemeijer, 1994), dan bahwa penemuan kembali (reinvention) ide dan konsep matematika tersebut harus dimulai dari penjelajahan berbagai situasi dan persoalan "dunia riil" (Lange, 1995). Selanjutnya dikatakan, jika kita (guru) rajin memperhatikan lingkungan dan mengaitkan pembelajaran dengan lingkungan maka besar kemungkinan berpikir ilmiah siswa itu akan tumbuh. Oleh karena itu, materi harus dipilih dan disesuaikan dengan lingkungan yang berkaitan dengan kehidupan sehari-hari (kontekstual) dan tingkat kognitif siswa, dimulai dengan cara-cara informal melalui pemodelan sebelum dengan cara formal. Hal ini sesuai dengan karakteristik RME. Ide utama dari RME adalah bahwa siswa harus diberi kesempatan untuk menemukan kembali (reinvent) ide dan konsep matematika dengan bimbingan orang dewasa melalui penjelajahan berbagai situasi dan persoalanpersoalan dunia nyata atau real world (Astuti, 2018)

Matematika merupakan alat pikiran, bahasa ilmu, tata cara pengatahuan, dan penarikan kesimpulan secara edukatif. Plato (Fathani, 2009) berpendapat bahwa matematika adalah identik dengan filsafat untuk ahli pikir, walaupun mereka mengatakan bahwa matematika harus dipelajari untuk keperluan lain. Objek matematika ada di dunia nyata, tetapi terpisah dari akal. Ia mengadakan perbedaan antara aritmatika (teori bilangan) dan logistik (teknik berhitung) yang diperlukan orang.

(Andrijati, 2014) Fenomena di sekolah menunjukkan bahwa dalam pembelajaran matematika masih terdapat kecenderungan guru jarang menggunakan media/alat peraga, guru menggunakan media/alat peraga seadanya atau sangat sederhana, jauh dari menarik perhatian siswa karena tidak memperhatikan komposisi warna, ukuran kurang proporsional, dan tidak dikemas dengan baik. Kondisi yang demikian menjadikan pembelajaran matematika tidak menarik, tidak menyenangkan, sehingga tidak optimal dalam membantu siswa untuk memperoleh konsep-konsep matematika. Seperti halnya pembelajaran matematika di SD Negeri Banyubiru 01 Kabupaten Semarang terdapat beberapa kekurangan diantaranya guru kurang melakukan variasi dalam pembelajaran, guru kurang memanfaatkan media untuk menunjang pembelajaran, serta guru kurang memperhatikan siswa yang kurang mampu dalam menguasai materi pembelajaran. Sementara siswanya kurang antusias, kurang tertarik dalam mengikuti pembelajaran, dan cenderung pasif serta lebih memilih berbicara sendiri. Hal ini menyebabkan materi yang diberikan guru kurang dapat diterima oleh siswa dengan baik, sehingga berdampak pada kurangnya pemahaman mengenai konsep matematika dan menyebabkan hasil belajar kurang optimal.

Permasalahan di atas di dukung dengan data hasil observasi dan evaluasi mata pelajaran matematika materi bangun datar pada siswa kelas II SD Negeri Banyubiru 01 Kabupaten Semarang, yaitu menunjukkan 58,33\% siswa belum mencapai ketuntasan kriteria minimal (KKM) yang ditetapkan sekolah yaitu 70, dengan keterangan sebagai berikut:

Tabel 1. Hasil Nilai Ulangan Harian Matematika Bangun Datar

\begin{tabular}{cc}
\hline Data Siswa & Keterangan \\
\hline 15 siswa & Tuntas \\
21 siswa & Belum tuntas \\
Nilai terendah & 50 \\
Nilai tertinggi & 85 \\
Nilai rata-rata & 67,4 \\
KKM & 70 \\
\hline
\end{tabular}

Dengan melihat hasil belajar siswa, maka perlu ditingkatkan kemampuan pemahaman konsep matematika pada materi bangun datar. Permasalahan mengenai kualitas pembelajaran matematika belum optimal merupakan masalah yang sangat penting dan mendesak, sehingga perlu dicari alternatif pemecahan masalahnya. Sebagai tindak lanjut untuk memecahkan masalah pembelajaran matematika materi bangun datar peneliti menetapkan alternatif tindakan untuk meningkatkan pemahaman konsep bangun datar dan melibatkan keterampilan siswa, maka peneliti menggunakan model RME. Menurut Gravenmeijer (Achmad Achmad \& Irmansyah, 2011) menyatakan bahwa: Model RME merupakan salah satu alternatif pembelajaran yang menuntut siswa untuk mengkontruksi pengetahuan dengan kempuannya sendiri melalui aktivitas yang dilakukannya dalam kegiatan pembelajaran. Ide utama 
pembelajaran dengan menggunakan model RME adalah siswa harus diberi kesempatan untuk menemukan kembali (reinventing) konsep matematika dengan bimbingan orang dewasa

Penerapan RME dalam pembelajaran akan menjadi lebih optimal dan efektif apabila didukung dengan media. Media merupakan sesuatu yang dapat menyampaikan pesan dan menciptakan suasana belajar yang kondusif, dengan begitu penerimanya dapat melakukan kegiatan pembelajaran secara efektif dan efisien, Munadi (Setiawan, 2017). Media yang cocok untuk mendukung model RME adalah dengan menggunakan media kertas lipat. Kertas lipat merupakan suatu kertas berbentuk persegi yang berukuran $(10 \times 10 \mathrm{~cm})$ dan berwarna-warni. Pemilihan penggunaan media kertas lipat itu sendiri karena kertas lipat memiliki beberapa kelebihan, diantaranya adalah: kertas lipat sangat mudah didapatkan di toko terdekat, kertas lipat sangat praktis untuk digunakan, varian warna pada kertas lipat dapat menarik perhatian siswa sehingga diharapkan siswa dapat termotivasi untuk belajar. Penelitian ini bertujuan untuk menjelaskan pengaruh model Realistic Mathematics Education (RME) berbantu media kertas lipat terhadap penanaman konsep bangun datar mata pelajaran matematika siswa kelas II SDN Banyubiru 01 Kabupaten Semarang.

\section{Metode}

Metode penelitian diartikan sebagai cara ilmiah untuk mendapatkan data dengan tujuan dan kegunaan tertentu (Sugiyono, 2015). Metode penelitian yang akan digunakan pada penelitian ini adalah metode eksperimen. Metode eksperimen merupakan metode penelitian yang digunakan untuk mencari pengaruh treatment (perlakuan) tertentu terhadap yang lain dalam kondisi yang dikendalikan (Sugiyono, 2015). Desain penelitian yang digunakan dalam penelitian ini adalah dengan Pre-eksperimental Design dengan model One-Group Pretest-Posttest Design. Pada desain ini, kelas di beri pre-test untuk mengetahui keadaan awal, selanjutnya kelas diberi perlakuan dengan model pembelajaran RME berbantu media kertas lipat pada saat pembelajaran materi Bangun datar. Tindakan selanjutnya diberi post-test. Prosedur penelitian sesuai dengan desain tersebut ditunjukkan pada gambar 1 berikut:

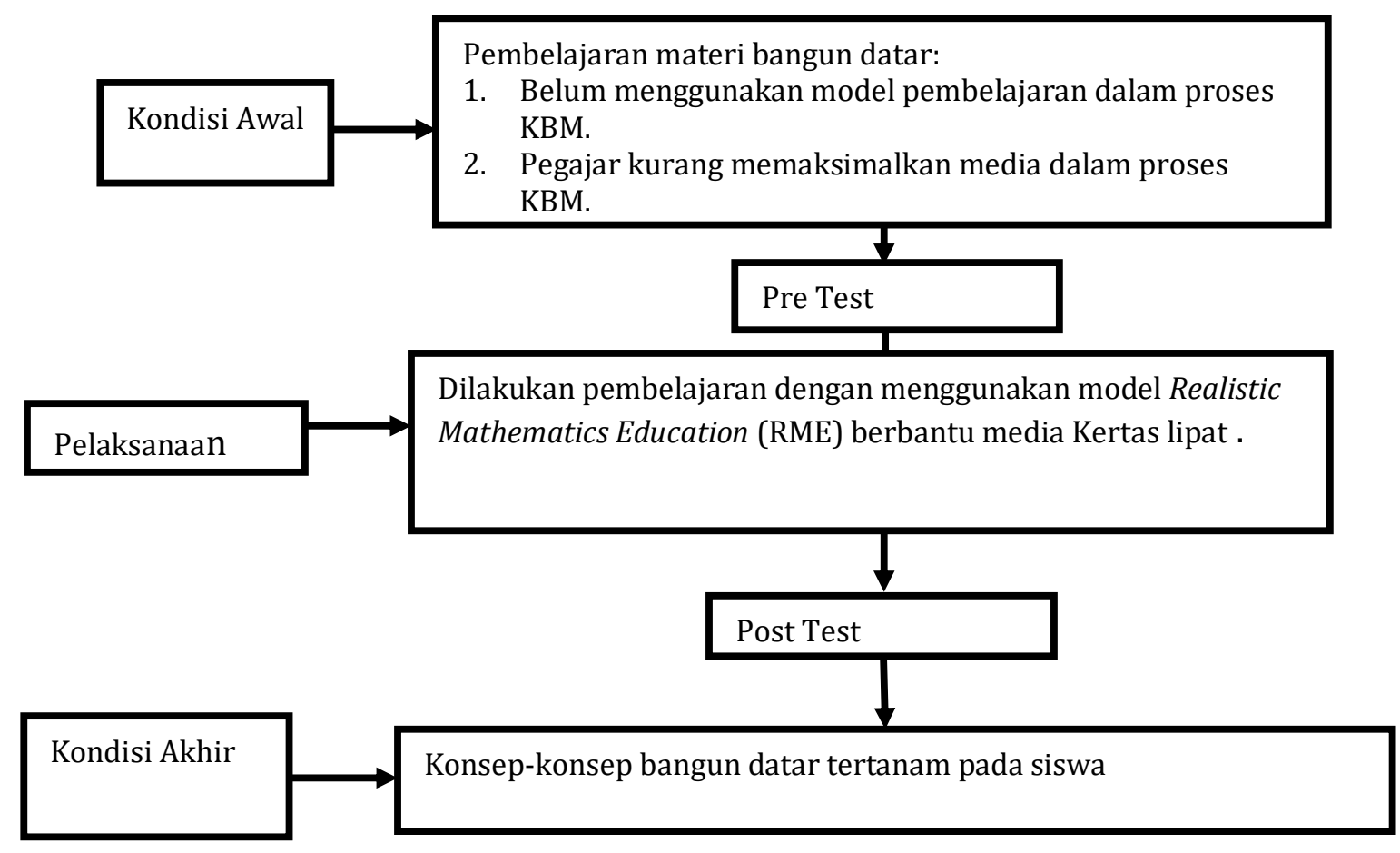

Gambar 1.

Bagan Prosedur Penelitian

Berdasarkan bagan di atas dapat diuraikan dalam penelitian ini, peneliti terlebih dahulu membuat soal berdasarkan kisi-kisi. Peneliti selanjutnya melakukan uji coba soal pada kelas yang dipilih. Uji coba soal ini bertujuan untuk mengetahui validitas butir soal, tingkat kesukaran dan daya beda melalui analisis data. Peneliti memulai dengan melakukan pretest. Pretest ini bertujuan untuk menganalisa data awal. Setelah diberi perlakuan, peneliti menggunakan soal posttest. Pemberian soal posttest ini bertujuan untuk mengetahui hasil posttest yang nantinya akan digunakan untuk menyusun hasil penelitian. 


\section{Hasil dan Pembahasan}

Penelitian ini dilaksanakan di SDN Banyubiru 01 Kabupaten Semarang dan membahas tentang pengaruh model RME berbantu media kertas lipat terhadap penanaman konsep bangun datar siswa kelas II. Penelitian ini merupakan penelitian kuantitatif. Dalam penelitian yang dilakukan peneliti yaitu Pre Experimen Design dengan jenis one group pretest-posttest design. Penelitian ini menggunakan teknik pretest-postest yang bertujuan untuk mengetahui secara efektif konsep yang tertanam. Pretest merupakan data awal yang diperoleh sebelum siswa diberi perlakuan dengan model RME. Posttest merupakan data akhir yang diperoleh setelah siswa diberi perlakuan dengan model RME.

Penelitian ini diawali dengan pembuatan soal uji coba mata pelajaran matematika materi bangun datar dengan jumlah soal sebanyak 40 soal pilihan ganda. Soal uji tersebut di ujikan kepada 20 siswa SDN Genting 02 Kabupaten Semarang. Dari soal yang telah di ujikan selanjutnya dianalisis untuk mengetahui jumlah soal yang memenuhi kriteria valid, reliabel, taraf kesukaran, dan daya pembeda. Nilai pretest dan posttest dinyatakan tuntas jika memenuhi Kriteria Ketuntasan Minimal (KKM). Adapun KKM mata pelajaran matematika SDN Banyubiru 01 yaitu 70. Perhitungan nilai pretest dan posttest setelah diberi perlakuan mendapatkan hasil yang berbeda. Berikut tabel nilai hasil dari pretest dan posttest siswa kelas II SDN Banyubiru 01 Kabupaten Semarang:

Tabel 2. Distribusi Nilai Pretest dan Posttest

\begin{tabular}{ccc}
\hline Kategori & Pretest & Posttest \\
\hline Terendah & 35 & 60 \\
Tertinggi & 75 & 95 \\
Rata-rata & 59,5 & 82,3 \\
\hline
\end{tabular}

Berdasarkan Tabel 2 nilai rata-rata pretest atau sebelum diberi perlakukan siswa SDN Banyubiru 01 adalah 59,5 dengan nilai terendah 35 dan nilai tertinggi 75. Siswa yang mendapat nilai diatas KKM yaitu 6 siswa (20\%) dan yang tidak tuntas 24 siswa (80\%). Setelah diberi perlakuan berupa penggunaan model RME berbantu media kertas lipat nilai rata-rata posttest mennjadi 82,3 dengan nilai terendah 60 dan nilai tertinggi 95 serta terdapat kenaikan jumlah siswa yang tuntas atau nilai diatas KKM yaitu sebanyak 27 siswa tuntas (90\%) dan sebanyak 3 siswa belum tuntas (10\%). Berdasarkan perbandingan data pretest dan posttest dapat disimpulkan bahwa perolehan data posttest lebih baik dibandingkan perolehan data pretest

Perhitungan yang digunakan untuk mengetahui normalitas data awal dan akhir sampel menggunakan uji Liliefors, pada taraf signifikan 5\%.

Tabel 3. Hasil Uji Normalitas Awal (pretest)

\begin{tabular}{ccccc}
\hline Kelompok & $\mathrm{N}$ & $\mathrm{L}_{0}$ & $\mathrm{~L}_{\text {tabel }}$ & Kesimpulan \\
\hline Kelas & 30 & 0,1468 & 0,161 & Berdistribusi Normal \\
\hline
\end{tabular}

Berdasarkan tabel 3 perhitungan uji normalitas diperoleh harga mutlak selisih yang paling besar. $\mathrm{L}_{0}$ $=0,1468$ dengan $n=30$ dan taraf signifikan $=5 \%$ dari daftar nilai kritis $\mathrm{L}$ didapat $\mathrm{L}_{\text {tabel }}=0,161$. Karena $\mathrm{L}_{0} \leq$ Ltabel yaitu 0,1468 $\leq 0,161$ maka $\mathrm{H}_{0}$ diterima sehingga populasi berdistribusi normal.

Tabel 4. Hasil Uji Normalitas Akhir (postest)

\begin{tabular}{ccccc}
\hline Kelompok & $\mathrm{N}$ & $\mathrm{L}_{0}$ & Ltabel & Kemimpulan \\
\hline Kelas & 30 & 0,0901 & 0,161 & Berdistribusi Normal \\
\hline
\end{tabular}

Berdasarkan Tabel 4 perhitungan uji normalitas diperoleh harga mutlak selisih yang paling besar. $\mathrm{L}_{0}=$ 0,0901 dengan $n=30$ dan taraf signifikan $=5 \%$ dari daftar nilai kritis $L$ didapat $L_{\text {tabel }}=0,161$. Karena $L_{0} \leq$ Ltabel yaitu 0,0901 $\leq 0,161$ maka $\mathrm{H}_{0}$ diterima sehingga populasi berdistribusi normal.

Hipotesis yang digunakan adalah sebagai berikut:

$\mathrm{H}_{\mathrm{o}}$ : Model RME berbantu media kertas lipat tidak berpengaruh terhadap penanaman konsep bangun datar siswa kelas II SD Negeri Banyubiru 01 Kabupaten Semarang.

$\mathrm{H}_{1}$ : Model RME berbantu media kertas lipat berpengaruh terhadap penanaman konsep bangun datar siswa kelas II SD Negeri Banyubiru 01 Kabupaten Semarang. 
Pengujian hipotesis antara dua variabel pada penelitian dilakukan untuk mengetahui pengaruh pembelajaran model RME berbantu media kertas lipat terhadap penanaman konsep bangun datar siswa kelas II SDN Banyubiru 01 Kabupaten Semarang. Pengujian tersebut dihitung menggunakan uji regresi sederhana. Dari hasil nilai keterampilan dan nilai penanaman konsep, diperoleh hasil sebagai berikut:

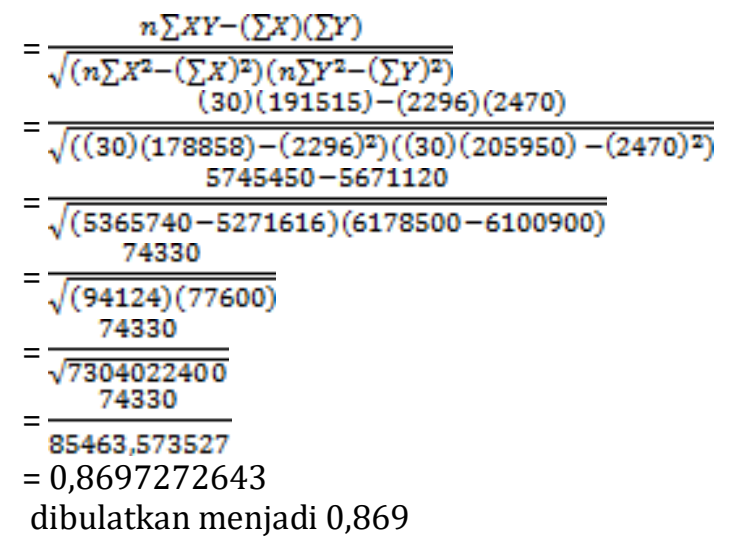

Simpulannya adalah, F hitung < F tabel sehingga regresinya linear. Berdasarkan hipotesis statistika yang peneliti lakukan, diperoleh $r_{\text {rabel }}$ untuk taraf kesalahan $5 \%$ dengan $n=30$ adalah 0,361. Karena rhtung lebih besar dari $r_{\text {tabel }}$ yaitu 0,869 > 0,361, maka dapat disimpulkan terdapat hubungan yang positif dan signifikan sebesar 0,869 antara keterampilan siswa dengan konsep matematika yang tertanam pada siswa. Koefisien determinasinya $r^{2}=0,869^{2}=0,755$. Hal ini berarti bahwa penanaman konsep matematika sebesar $75 \%$ ditentukan oleh keterampilan siswa, melalui persamaan $Y=-1,21621+0,7897 \mathrm{X}$. Sisanya sebesar 25\% ditentukan oleh faktor lain.

Data hasil observasi dan evaluasi mata pelajaran matematika materi bangun datar pada siswa kelas II SD Negeri Banyubiru 01 Kabupaten Semarang, yaitu menunjukkan 58,33\% siswa belum mencapai ketuntasan kriteria minimal (KKM) yang ditetapkan sekolah yaitu 70,

Dengan melihat hasil belajar siswa, maka perlu ditingkatkan kemampuan pemahaman konsep matematika pada materi bangun datar. Permasalahan mengenai kualitas pembelajaran matematika belum optimal merupakan masalah yang sangat penting dan mendesak, sehingga perlu dicari alternatif pemecahan masalahnya. Sebagai tindak lanjut untuk memecahkan masalah pembelajaran matematika materi bangun datar peneliti menetapkan alternatif tindakan untuk meningkatkan pemahaman konsep bangun datar dan melibatkan keterampilan siswa, maka peneliti menggunakan model RME berbantu media kertas lipat.

Instrument penelitian yang dipilih dalam penelitian ini yaitu berupa tes yang berisikan 20 soal pilihan ganda. Hasil penelitian menunjukkan bahwa nilai penanaman konsep peserta didik pada uji pretest didapatkan nilai terendah sebesar 35, nilai tertinggi sebesar 75 dan nilai rata-rata sebesar 59,5. Sedangkan pada uji posttest didaparkan nilai terendah sebesar 60, nilai tertinggi sebesar 95 dan nilai ratarata sebesar 82,3.

Untuk mengetahui normalitas sampel dari populasi, dalam penelitian ini menggunakan perhitungan uji liliefors. Pada taraf signifikan $5 \%$ dan $\mathrm{n}=30$. Uji normalitas dilakukan dengan data awal (pretest) dan data akhir (posttest). Uji normalitas data awal (pretest) untuk $\mathrm{n}=30$ dan taraf signifikan $5 \%$ dengan metode lilieforsdiperoleh Lhitung $=0,1468$ dan Ltabel $=0,161$. Dari data tersebut dapat disimpulkan bahwa Lhitung $<$ Ltabel. Sehingga $\mathrm{H}_{0}$ diterima. Jadi sampel berasal dari populasi yang berdistribusi normal. Uji normalitas data akhir (posttest) untuk $\mathrm{n}=30$ dan taraf signifikan 5\% dengan metode liliefors diperoleh $\mathrm{L}_{\text {hitung }}=0,0901$ dan $\mathrm{L}_{\text {tabel }}=0,161$. Dari data tersebut dapat disimpulkan bahwa $\mathrm{L}_{\text {hitung }}<\mathrm{L}_{\text {tabel. }}$ Sehingga $\mathrm{H}_{0}$ diterima. Jadi sampel berasal dari populasi yang berdistribusi normal.

Berdasarkan perhitungan koefisien determinasinya $r^{2}=0,869^{2}=0,755$. Hal ini berarti bahwa penanaman konsep matematika sebesar 75\% ditentukan oleh keterampilan siswa, melalui persamaan Y= $1,21621+0,7897 X$. Sisanya sebesar $25 \%$ ditentukan oleh faktor lain.

(Aris, 2014) Kelebihan model RME diantaranya: a) Pembelajaran matematika realistik memberikan pengertian yang jelas kepada siswa tentang kehidupan sehari-hari dan kegunaan pada umumnya bagi manusia b) Pembelajaran matematika realistik memberikan pengertian yang jelas kepada siswa bahwa matematika adalah suatu bidang kajian yang dikontruksi dan dikembangkan sendiri oleh siswa, tidak hanya oleh merek yang disebut pakar dalam bidang tersebut; c) Pembelajaran matematika realistik memberikan pengertian yang jelas kepada siswa cara penyelesaian suatu soal atau masalah tidak harus tunggal dan tidak harus sama antara yang satu dengan yang lain. 
Teori-teori tersebut telah terbukti dengan hasil penelitian selama penelitian berlangsung. Selain itu juga teori tersebut sesuai dengan kenyataan saat berada dilapangan. Pola interaksi peserta didik selama berlangsungnya kegiatan belajar mengajar pada saat penelitian sangat baik. Peserta didik sangat antusias dalam mengikuti pembelajaran, peserta didik bersifat lebih aktif, reaktif dan munculnya rasa ingin tahu peserta didik yang tinggi.

\section{Simpulan dan Saran}

Berdasarkan hasil penelitian dan pembahasan dalam penelitian ini dapat disimpulkan bahwa terdapat pengaruh yang positif dan signifikan antara keterampilan siswa dengan penanaman konsep bangun datar mata pelajaran matematika siswa kelas II SDN Banyubiru 01 melalui penggunaan model RME berbantu media kertas lipat. Hal ini dapat diperkuat dengan hasil data sebagai berikut: Rata-rata nilai pretest atau sebelum diberi perlakuan menggunakan model RME adalah 59,5 dan rata-rata nilai posttest atau setelah diberi perlakuan menggunakan model RME adalah 82,3; Dalam perhitungan uji regresi diperoleh harga rhitung $=0,869$ sedangkan harga rtabel $=0,361$, karena rhitung $>$ rtabel , maka hipotesis nol (HO) ditolak dan hipotesis alternatif (Ha) diterima. Dapat disimpulkan bahwa model Realistic Mathematics Education (RME) berbantu media kertas lipat berpengaruh terhadap penanaman konsep bangun datar mata pelajaran matematika siswa kelas II SDN Banyubiru 01 Kabupaten Semarang.

Dari hasil penelitian, saran yang dapat diajukan penulis adalah sebagai berikut: 1) Untuk Penulis Selanjutnya Penulis berharap agar penulis pada penelitian selanjutnya dapat mengembangkan penggunaan model RME berbantu media yang lebih kreatif dan inovatif. 2) Untuk Guru Penulis berharap model RME dapat digunakan guru sebagai salah satu model pembelajaran alternatif, karena model tersebut merupakan model yang menarik dan mudah diterapkan khususnya pada mata pelajaran matematika sebab model ini mengacu berdasarkan pengalaman siswa dan benda-benda nyata atau konkrit. 3) Untuk Sekolah Penulis berharap agar sekolah dapat memberikan dukungan penuh terhadap guru apabila dalam proses pembelajaran guru menggunakan model RME, supaya tujuan pembelajaran dan hasil belajar siswa dapat tercapai secara maksimal.

\section{Daftar Rujukan}

Achmad Achmad, \& Irmansyah. (2011). Efektifitas Pembelajaran Matematika Melalui Model Pembelajaran Realistic Matematic Education (Rme) Terhadap Peningkatan Pemahaman Konsep Matematika Siswa Sd. Jurnal Pendidikan, 12(1), 33-40. https://doi.org/10.33830/jp.v12i1.483.2011

Andrijati, N. (2014). Penerapan Media Pembelajaran Inovatif Dalam Pembelajaran Matematika Sekolah Dasar Di Pgsd Upp Tegal. Jurnal Penelitian Pendidikan, 31(2), 123-132. https://doi.org/10.15294/jpp.v31i2.5696

Aris, S. (2014). Model pembelajaran Inovatif Dalam Kurikulum 2013. In 1 (Issue). Yogyakarta: AR-ruz media.

Astuti, A. (2018). Penerapan Realistic Mathematic Education (Rme) Meningkatkan Hasil Belajar Matematika Siswa Kelas Vi Sd. Jurnal Cendekia: Jurnal Pendidikan Matematika, 2(1), 49-61. https://doi.org/10.31004/cendekia.v2i1.32

Fathani, A. H. (2009). Matematika Hakikat \& Logika. Ar-Ruzz Media.

Gravemeijer. 1994. Developing Realistic Mathematics Education. Utrecht: Freudenthal Institute. http://repository.upi.edu/operator/upload/d mat-0604957 chapter2.pdf

Lange, J. De. (1995). Assessment: No change without problems. ... in School Mathematics and Authentic Assessment, 1-28. https://doi.org/10.2170/physiolsci.RP000705

Monawati. (2017). Hubungan Antara Kecerdasan Interpersonal Dengan Prestasi Belajar. Jurnal Pesona Dasar, 3(3), 21-32.

Setiawan, F. (2017). Upaya Meningkatkan Hasil Belajar Siswa Dengan Menggunakan Media Kertas $\begin{array}{lllll}\text { Origami. Jurnal Bidang Pendidikan } & \text { 78-85. }\end{array}$ http://ejournal.unikama.ac.id/index.php/JBPD

SIRAIT, E. D. (2016). Pengaruh minat belajar terhadap Prestasi Bekajar Siswa PAI. Formatif : Jurnal Ilmiah Pendidikan MIPA, 6(1), 35-43.

https://doi.org/http://journal.lppmunindra.ac.id/index.php/Formatif/article/viewFile/750/659 
Suwartini, Sri. 2017. Pendidikan Karakter Dan Pembangunan Sumber Daya Manusia Keberlanjutan. Trihayu: Jurnal Pendidikan Ke-SD-an, Vol. 4(1); (220-234).

Sugiyono. (2015). Metode Penelitian Pendidikan (Pendekatan Kuantitatif, Kualitatif, dan R\&D). Alfabeta. Undang-undang (UU) Nomor 14 Tahun 2005 tentang Guru dan Dosen. 